\title{
UAB
}

Universitat Autònoma

de Barcelona

This is the accepted version of the article:

Rambla, Francesc Xavier. «The politics of early school leaving: how do the European Union and the Spanish educational authorities 'frame' the policy and formulate a 'theory of change'». Journal of European Integration, Vol. 40 Núm. 1 (2018), p. 83-97. DOI 10.1080/07036337.2017.1404053

This version is avaible at https://ddd.uab.cat/record/207947

under the terms of the C ${ }_{\text {COPYRIGHT license }}^{\mathbb{I N}}$ 
The politics of early school leaving: how do the European Union and the Spanish educational authorities 'frame' the policy and formulate a 'theory of change'

The final version of this paper was published in:

Rambla, X. (2018) The politics of early school leaving: how do the European Union and the Spanish educational authorities 'frame' the policy and formulate a 'theory of change', Journal of European Integration 40 (1), 83-97

\begin{abstract}
The article analyses the interaction between the European Commission and a sample of educational authorities in Spain with regard to the policy against early school leaving. Although this member state scores the highest proportion of early school leavers, apparently it is not adopting some key recommendations issued by the Commission. In fact, while educational policy studies regret this “resistance”, studies on EU policies suggest that the EU and the states normally negotiate the ambition and the evaluation of policies in complex ways. In this vein, the article draws on a method of discourse analysis to observe to what extent these educational authorities 'frame' the policy in the same terms and share a similar rationale or 'theory of change'. In brief, the findings point out that the EU, the Government of Spain and two significant regional governments retrieve a similar 'frame' but do not agree regarding the 'theory of change'.
\end{abstract}

KEYWORDS.- Europeanisation. Early school leaving. Educational policy-making. Discursive institutionalism.

\title{
Introduction
}

Between 2001 and 2010 the Lisbon Agenda put competitiveness and social cohesion high in the agenda of the European Union. Since 2010, the Europe 2020 Strategy has adopted similar goals so as to foster smart, inclusive and sustainable growth. In this vein, the European Council and the European Commission have designed a wide-ranging policy framework addressed to effectively reduce early school leaving to $10 \%$ of each cohort by the end of the decade. However, an official report has already noticed that, despite a positive trend, the rhythm of actual reduction is too slow to 
achieve the target by 2020 (EACEA, European Commission and EURYDICE, 2013: 21-22).

The analysis of this policy benefits from insights suggested by previous research on comparative education and European policy studies. Experts in education policy have repeatedly argued for an encompassing approach that tackles all the factors that induce students to drop out of either academic or vocational secondary education (NESSE, 2009). As a consequence, the official guidelines recommend to prevent the problem in advance, to intervene on the conditions of the students exposed to this risk, and to compensate actual early school leavers so that they improve their education and skills. However, a recent appraisal of the current trends has observed a widespread "resistance to EU policies" among the governments of the member states (Timmerman \& Willems, 2015: 17).

This article draws on studies of both EU policies and education policy to spell out the clues of this “resistance to EU policies". The first two sections introduce the theoretical rationale and the method of research. Then, two latter sections present the results of a discourse analysis of the 'frame' and the 'theories of change' used by decision-makers.

\section{The European Union and education policy}

Since the Lisbon Agenda was launched in 2001, the Commission and the Council have actively attempted to persuade member states to align their education, labour market and youth policies with a core set of premises. The rationale of this policy is that these three areas have to match with one another in order to both underpin social cohesion and strengthen skills development (Ruiter, 2010; Nicaise, 2012). This endeavour has eventually contributed to shape a European social field of education policy (Dale \& Robertson, 2009; Stéger, 2014), where the Commission has actively looked for an alliance with the OECD (Grek, 2010, 2013; Lingard et al, 2013).

Nevertheless, although the mainstream guidelines remind decision-makers of the varied connections between education and other policy areas, a growing number of studies on education policy find out that member states seldom adopt these recommendations. First, in 2010 the bulk of the Lisbon Agenda goals was included in the Europe 2020 Strategy, but the significant underachievement of the previous phase was neither clearly recognised nor systematically evaluated (Pépin, 2011). 
Second, images of 'fit' between the EU and the member states policies are explicitly constructed with varied intentions. For instance, some small member states and some regions who wanted to distinguish their education policy from the larger state used the Lisbon Agenda to launch their own strategic plans (Rambla, 2013). Alexiadou et al (2010) and Alexiadou \& Lange (2013) also notice that some governments actively give a low profile to the relation between their education policy and that of the EU. Third, despite the common guidelines set by the Lisbon Agenda and the Europe 2020 Strategy, the understanding of many concepts diverges across member states. For instance, comparative findings have detected disparate understandings of quality assurance in England, Scotland and Sweden (Ozga et al, 2011a; Croxford et al, 2009). Disparities are also remarkable regarding centralisation and decentralisation in England, Finland, France, Germany, Scotland and Sweden (Ozga et al, 2011b; Dupuy, 2012). Forth, the conclusions of a recent study on governance of educational transitions - conducted across a varied sample of member states, already noticed that different political strategies are currently launched at the EU, member state and local levels. The decisions made at each level are only partially aligned with the decisions made at the other ones. Thus, sometimes educational policy-makers ignore the other levels (Parreira do Amaral et al, 2015). The outcomes depict a large landscape of empirical variations.

The literature on policy-making in the European Union posits a complementary perspective that contributes to make sense of this apparent paradox. In fact, both the EU and the governments of the member states draw on sophisticate discursive strategies to pursue their interests in the multilayered space of European politics (Jessop, 2007; Keating, 2009; Radaelli et al, 2013). Eventually, these actors shape a social field where they negotiate and influence one another.

The Commission often looks for recognition by calling for impact assessments of its own policies, and engages in reinterpretation by using the corresponding publications to actively craft the public image of its own activities (Radaelli et al, 2013; Adler-Nissen \& Kropp, 2015). At the same time, European policies normally respond to the interests of power coalitions that produce and deploy discourses to legitimize their interests (Carstensen \& Schmidt, 2016). Similarly, the education policy of the EU fashions a complex social field (Dale and Robertson, 2009; Parreira do Amaral et al, 2015) where authorities experiment with varied modes of policy learning. In Spain, educational authorities seem to have adopted EU policies to reduce early school leaving in a 'competitive' way (Lange \& Alexiadou, 2010). Instead of reviewing their whole approach (i.e. engaging in 'mutual 
learning'), policy-makers proclaim their endeavour to meet the official benchmark but deflect the recommendations of the European Council and the European Commission.

This article draws on discursive institutionalism in order to spell out some clues of the currently mainstream policies against early school leaving. In contrast with post- modernist and poststructuralist hermeneutics, critical discourse analysis does not assume that discourses constitute reality. On the contrary, the starting point claims that discourse is a social practice whereby social agents deal with meaning and communication. But these agents undertake other social practices such as weaving social networks or following institutional path dependencies that are not intrinsically discursive. Beyond the scope of linguistics, social sciences may be interested in discourse insofar as it is an entry point to observe some particular phenomena (Schmidt, 2008).

Critical discourse analysis highlights some rhetorical devices whereby social agents set the limits of a particular stance. Crucial to this function is the usage of the catchwords that align a variety of concepts with a coherent discourse (Fairclough, 2003: 133). This discourse 'frames' the strategy of the EU to tackle early school leaving. Framing consists of organising subjective experience so that the audience associates some concepts automatically with other ones (Goffman, 1997). In politics, social movements use frames to justify their vindications and denigrate the position of opposing parties (Bedford and Snow, 2000). Political actors often frame such themes as new public management or Europeanisation (Diez, 1999; Vogel, 2012). Therefore, in accordance with the results of other studies on the European Union, it is relevant to inquire whether the Commission and the Council share the same catchwords with the national and regional governments of some member states.

Statements of fact are another key rhetorical instrument of political discourse. These statements convey knowledge exchanges between social agents such as policy actors (Fairclough, 2003: 119). A growing strand of research increasingly shows that international development programmes (Stein \& Valters, 2012), public policies (Stame, 2004; Roberts, 2008) and even financial strategies (Jackson, 2013) rely on sets of statements of fact that connect definitions of problems with alleged solutions. Normally, these studies label these sets of statements as 'theories of change'. Policy and international relations scholars also capture this feature of political discourse when discussing the growing influence of epistemic communities in linking problems with solutions (Croxford et al, 
2009; Davis Cross, 2013).

Unsurprisingly, ‘theories of change’ are a common resource in European politics (Radaelli et al, 2013; Carstensen \& Schmidt, 2016) as well as in European education policy-making (Auld and Morris, 2014; Simola et al, 2011; Lingard et al, 2013; Grek et al, 2009a, 2009b). Therefore, these researches also suggest that the reception of the message of the EU on early school leaving by member state governments can also be scrutinised by exploring to what extent both parties share the same 'theory of change'.

\section{Context, corpus of discourse and coding}

The article explores to what extent, in Spain, a number of educational authorities adopted the EU 'frame' and 'theory of change' regarding early school leaving during the Conservative administration that was in office between 2012 and 2016. This section will briefly report on the main methodological decisions taken by the researcher regarding the sample of educational authorities, the corpus of documents and coding.

The sample of educational authorities is composed by the governments of Spain as well as the regions of Andalusia and Catalonia. Spain is the EU member state with the highest rate of early school leavers. Although some improvement has been noticeable since 2008, progress has not been as significant as in Malta and Portugal, which are the other two extreme cases (European Commission, 2012b).

In Spain, since the majority of educational competencies were transferred from the central to the regional governments between 1980 and 2000, policies on early school leaving are also coordinated among layers of governance. Basically, the central government issues framework laws, which must be supported by a qualified majority, to define the curriculum, the legal status of public and private schools, the status of teachers' jobs, the model of school organisation and certain specific programmes fostering coordination between regions. Regional governments are in charge of human-resource management and language policy if Spanish is not the only official language in their territory. These authorities are also responsible for particular aspects of the curriculum, school organisation and their own specific programmes. 
The main policy approach to early school leaving was formulated by a framework act approved by the last Socialist administration in 2006 (GovSpain-MoE, 2006). This piece of legislation required to tackle early school leaving by offering remedial courses to students at the last year of the compulsory, comprehensive lower- secondary education. It also asked educational authorities to offer initial vocational training programmes to the sixteen- years- olds who were either repeating grades or had failed to get their secondary education certificate. Initial vocational training mostly had to encourage students to get back to regular schooling and take their secondary education certificate exams. The 2006 act also intended to coordinate central and regional policies against early school leaving. Thus, both levels of government contributed to fund programmes that delivered academic and leisure after-school activities to the most vulnerable students (Manzanares \& Ulla, 2012). But these programmes were severely downsized because of the fiscal adjustments starting in 2010.

In 2013, a Conservative administration reformed the framework education act substantially (GovSpain-MoE, 2013). A number of articles were changed in order to introduce external, compulsory examinations for all schools, and establish a new division of the whole lower secondary education into academic and vocational tracks. Thus, the remedial and initial vocational training programmes established in 2006 were scaled up so as to distribute all thirteen- year- olds either in academic or in these newly vocational tracks. Since most regional governments were led by the Conservative party between 2011 and 2015, many of them welcomed this approach.

Both the governments of Andalusia and Catalonia had previously decided to pass their own Education Act on the grounds of the 2006 Organic Act. This is a plausible criterion to include them in the sample. However, looking at these two regions is also relevant for other reasons. First, they are the most populated of the seventeen autonomous regions. Second, while Catalonia is slightly wealthier than other regions in terms of income per capita, the score of Andalusia is significantly lower. Third, both of them were governed by opposition parties between 2012 and 2016. The Socialist party was in office in Andalusia, as it has been since the eighties. The Nationalist Liberal Party was in office in Catalonia between 2011 and 2015. Although it received the support of the Spanish Conservative Party at the beginning, this alliance collapsed when the Catalan Liberal Nationalists endorsed the campaign for independence in late 2012. Therefore, since a sample 
including these two regions accounts for socio-economic and ideological disparities, any similarity between their official discourses on education policy is particularly telling.

The corpus of discourse is the list of documents taken into consideration for an analysis (Fairclough, 2003). In this research, such corpus was built by means of document search and interviews. Eventually, it contains references to some interviews conducted between 2013 and 2015 in Brussels, Madrid and Barcelona. Although similar interviews were conducted in Andalusia, finally they were not used.

Table 1 lists the selected documents. These pieces have been issued by a variety of political actors. The Commission and the Council were in conversation with the OECD and several networks of experts and civil society representatives. The selected educational authorities also produced their own views on their policy. Thus, it is plausible to ask whether this network of political actors shared the same frame and theory of change. Coincidence would be especially relevant, since the very diversity of voices at first suggested that some divergence was likely.

\section{TABLE 1 AROUND HERE}

The documents were coded in an inductive way (Corbin \& Strauss 1990). First, their references to the main concepts of the EU framework were identified. This operation produced lists of references to 'prevention', ‘intervention', compensation' and ‘coordination between governments'. Second, each list was closely analysed in order to find out similarities and differences. The RQDA package was used for this purpose (Huang, 2014). The following two sections report on the results of these analyses. The first one observes to what extent this sample of educational authorities framed their policy against early school leaving in the same way as the European Commission. Then, another section compares the views of the different authorities regarding the 'theory of change' whereby early school leaving was to be reduced.

\section{Common frame but different understandings}

At the very beginning of the Europe 2020 Strategy the European Council (2011) issued a Recommendation on policies to reduce early school leaving. That text shares a constellation of 
references to prevention, intervention and compensation with many other statements of the European Commission (2012c, 2012d, 2013a, 2013e). Remarkably, other actors coincide exactly in the same terms, namely the OECD (2012), some networks of experts (NESSE, 2009; Oomen and Pang, 2014), and some civil society organisations such as COFACE (2010), ETUCE (2011, 2013) and EUNEC (2014).

In this view, prevention has to do with wide, societal factors that may reduce the risk of early school leaving. For the EU, preventative measures may deal with general themes as the quality of childhood or the design of an encouraging curriculum. Other measures consist of implementing more specific policies addressing segregation, the needs of schools in disadvantaged areas and the value of language diversity. Prevention also requires designing a strong career guidance system. Intervention and compensation are the other two instruments of a policy that deals with early school leaving. Intervention must consist of early warning systems, a focus on individual needs, systematic support, extra-curricula and out-of-school activities, and support to teachers and families. Compensation has to draw on second chance courses, recognition of competences and local, proactive outreach action to find early school leavers (European Council, 2011: C191/4-5, European Commission, 2013a: 12).

Certainly, over time governments have taken some preventative measures in Spain. For instance, early childhood education and care was notably improved in the nineties. In 2006 the coordinated programmes supported schools in disadvantaged areas. In 2013, the minister of education evoked prevention to argue that the new reform strengthened the flexibility of educational pathways insofar as headteachers could decide which tracks were offered in each school and recruit part of the teaching staff accordingly (Wert, 2013: 7).

Nevertheless, although all the governments included in the sample retrieved the EU strategy for the sake of legitimation, eventually they understood prevention in a very restrictive way. To start with, when the Government of Spain reported on the measures adopted by the regional educational authorities, the official report coincided with the Commission to portray support to disadvantaged zones as a measure of prevention. But remarkably, it assumed that school strategies targeted to students with either low performance or special education needs were also preventative measures. Interestingly, the Commission classifies the same measures as intervention (European Commission, 
2013a: 12).

As a rule, regional governments implement school strategies and programmes aiming at academic success by supporting and fostering instrumental forms of learning that lead to better educational results. They also cater to the most disadvantaged zones and populations at risk of exclusion, who therefore are exposed to a higher risk of early leaving. Most regions strengthen academic guidance and remedial courses as soon as any shortcoming in the basic competences of a student is detected. Thus, the education process may pursue properly. An array of programmes catering to special education needs are another widespread preventative measure (MECD, 2013: 70).

The Government of Andalusia designed a particular policy against early school leaving. It followed the central government as far as initial vocational courses for low-performers and coordinated support for vulnerable students were concerned (GovAndalusia-MoE, 2007). But it also launched an experiment with pedagogic innovation, and implemented a social benefit targeted to low-income students. This benefit delivers $600 €$ per year if these students enrol in either academic or vocational post-compulsory programmes (GovAndalusia-MoE, 2011, 2012). At first sight, this measure has to do with intervention through support to families and students. But the official description claims that it is a preventative measure.

Scholarship 6000 [supports] low-income students so that they complete their compulsory education and enrol in either academic or vocational post-compulsory courses. In the 200910 school year the Ministry of Education of Andalusia implemented Scholarship 6000 in order to achieve two goals. First, this programme is expected to prevent early school leaving and posit incentives for further education. Second, it has to compensate families and individuals for the income they do not earn when the youth remain at school after sixteen (GovAndalusia-MoE, 2016).

In 2012, the Government of Catalonia launched a strategic plan to foster school success. The first line of action somehow retrieved the idea of prevention at the societal level by improving teachers' professionalism. But all the other ones explicitly focused on intervention on intra-school processes. In this view, early school leaving was conflated with absenteeism and had to be mostly addressed by means of compensation.

The following guidlines pursue these goals. The guidelines eventually pattern the action of the Ministry of Education of Catalonia in both compulsory and post-compulsory school programmes. (1) Improving teachers' professionalism. (2) Providing personalised support to tackle learning problems in early childhood and primary education. (3) Focusing on literacy and reading. (4) Pedagogic innovation in the classroom. (5) Improving communication, intercultural education and multilingualism so as to improve students' language skills. (6) School autonomy. (7) Professionalising the role of principals. (8) Involving families in students' academic and personal development. (9) Relationships with the educational community. (10) Absenteeism and early school leaving: initiatives and training strategies favouring the return to the educational system of person who previously dropped out 
(GovCatalonia-MoE, 2012: 20-26).

Significantly, the Conservative central administration shared this restrictive understanding with the Socialist government of Andalusia and the Nationalist Liberal government of Catalonia. The fact that educational authorities overlooked the definition of prevention circulated by the Commission is not only surprising because Spain scored the highest rate of early school leavers in the European Union. The point is that the prevailing approach in Spain also disregarded the problems of disadvantaged students. Remarkably, in Spain many students repeat grades from the very primary education, and their average academic performance is also quite low compared to repeating students in other OECD countries (OECD, 2014b: table IV 2.2). Moreover, the percentage of disadvantaged students who attend disadvantaged schools is higher in Spain than in the OECD average (OECD, 2011: 93, figure II 5.6; OECD, 2014b). The mainstream reading of prevention in the country did not take curriculum and teaching practices into account either. However, according to the OECD (2014b: table 6.1), in Spain only 33\% of secondary education students work in small groups to come up with a joint solution to a problem or task. The figure contrasts with $79 \%$ in Denmark, 36,8\% in France, and 58,4\% in England. Similarly, compared to 45\% in Denmark, 75\% in France, and 17\% in England, in Spain 85\% teachers never observe other teachers' classes and provide feedback (OECD, 2014: figure 6.10).

Notably, divergence regarding the scope of prevention did not trigger conflict between the European institutions and the Government of Spain. Thus, the introduction of early tracking within the compulsory lower-secondary programme in 2013, at first sight, departed from the guidelines of the European Commission (2013a). But the role of member states in EURYDICE did not seem to allow for highlighting this disparity so much so that in 2014 the report conceded that the new education act might eventually underpin the flexibility of pathways (European Commission, EACEA, EURYDICE \& CEDEFOP, 2014).

\section{Overlapping but disparate theories of change}

Critical discourse analysis is helpful to spell out the semantic relations of synonymy and antonymy that the European Commission established between early school leaving, on the one hand, and prevention, intervention and compensation, on the other hand (Fairclough, 2003: 133). Firstly, due to the alleged damage for the potential for smart, inclusive and sustainable growth, early school 
leaving was featured as synonymous with a problem and an economic cost. Secondly, the chain of prevention, intervention and compensation became synonymous with both the solution and a possible economic saving. These semantic relations constructed a 'theory of change' whereby the problem was antonymous with the solution as well as the cost with the saving (European Commission, 2013a; European Commission, EACEA and EURYDICE, 2013; European Commission, EACEA, EURYDICE and CEDEFOP, 2015).

In 2013 interviewees from the Commission staff admitted that only a few member states were fully implementing the common strategy, but they suggested that this strategy could become a significant criterion to evaluate social funds in the middle term. At that time, the official position stated that multidimensional action was the appropriate response to a multi-faceted problem (European Commission, 2013a: 3). The EU claimed that properly aligned measures were likely to reduce early school leaving. Generally speaking, this opinion was widely shared by the OECD (2007), the European teachers union (ETUCE, 2011, 2013) and networks gathering school councils (EUNEC, 2014) as well as experts on educational studies (NESSE, 2009), economics of education (Brunello \& de Paola, 2013) and career guidance (Oomen \& Plang, 2014).

The work of the TWG on ESL [early school leaving] has confirmed that good results in reducing ESL can only be obtained if a comprehensive strategy is in place, based on strong and continuous political commitment of all stakeholders in its implementation, at all levels. The TWG has highlighted the importance of striking the right balance between central and local measures, and between preventative, intervention and compensation measures. It has confirmed that the strong involvement and commitment of parents, students, local communities, youth, social and employment services and businesses is essential in developing and implementing policies against ESL. The key policy messages presented on page 3 reinforce the need for a comprehensive approach to ESL. Schools cannot and should not work in isolation (European Commission, 2013a: 25)

Somehow, the official European theory of change overlapped with the prevailing one in Spain insofar as careful semantic nuances helped all policy-makers to find some common ground. Thus, in accordance with the insistence on an alleged compliance of central and regional authorities with the European strategy (Government of Andalusia, 2007, 2011; Rigau, 2012; Wert, 2013), EURYDICE monitoring reports simultaneously reminded of the need of comprehensive action and conceded that Spanish authorities were active in reducing early school leaving (European Commission, EACEA, EURYDICE and CEDEFOP, 2015).

Nonetheless, this careful wording could not conceal that in Spain most policy-makers thought that, 
simply, internal school processes were effective on their own. Thus, the Government of Spain expected that vulnerable students stayed at school if an adapted curriculum stressing literacy, numeracy, organisation skills and academic attitudes catered to their specific needs. In this view, the system was too rigid for those students whose expectations did not comply with the norm. The corollary was that if they were allowed to choose between different tracks, they were more likely to feel comfortable and would decide to continue within the system, thus availing of greater possibilities to improve their personal and professional future development (Government of Spain, 2013: 97864). Compared to the Commission, no reference was made to a comprehensive strategy, community involvement was neglected, and systematic support was not connected to this policy. These discrepancies with the Thematic Working Group (European Commission, 2013a: 25) indicated that the educational authorities of the Union and the member state did not adopt the same theory of change. Similarly, in 2013 I interviewed officers of the Ministry who insisted on the potential of diverse tracks to convince teenagers to finish compulsory education and enrol in further education.

How does the system deal with children? Why do they leave at a given point? In our view, the problem is that the pathways are neither defined nor adapted to the talents of each child. Thus, at a given point equal opportunities are conveyed by such an uniform approach that they cannot choose the pathway that suits their capabilities best (...) Therefore, the Organic Act on the Quality of Education advances the age when they have to choose a pathway. The European experience shows that this scheme works in countries when the first (but reversible) decision is made at fourteen. Our proposal includes an array of pathways so that a child can go back at any moment if s/he chose (let's say) applied mathematics but afterwards regretted this choice.

When he presented the new Education Act to the Parliament, the Minister underpinned this thesis with another argument. In his terms, an evidence-based review of education policies in the OECD and EU countries eventually showed that this type of flexibility and legal reforms that changed school practices were sound strategies to increase performance.

Definitely, lords and ladies, the countries which were successful in improving their educational performance did so by means of the appropriate legal reforms. These reforms take care of the students' diversity of abilities, deliver an individualised education and a wider flexibility of pathways, put in place more demanding academic standards, and value effort on the grounds of evaluation. Teachers are well trained and schools are allowed to be autonomous enough to specialise and provide students with a larger educational supply. These measures propose changes in the curriculum, the methodology, the pedagogy and the academic standards, but all of them are aligned with the aforementioned three general goals: reducing early school leaving, improving the quality of teaching and increasing employability. They are evidence-based measures. Neither the measures established by the new education act concerning the architecture of the system nor the changes proposed by 
this act respond to caprice or improvisation. On the contrary, this line of action responds to the educational reforms which have been more successful in a variety of countries (Wert, 2013: 7-10).

As mentioned before, the Government of Andalusia implemented a scholarship to tackle early school leaving. Additionally, in 2012 it passed a decree opening a call for schools to be labelled as learning communities, and thus become eligible for extra-support. Clearly, the rationale of this decree emphasised the hypothesis that transforming the internal processes of schools would render the main progress.

Article 2. Definition of "learning communities" projects

1. A "learning community" is a project of social and cultural transformation of a school and its community. The main goals are improving the academic performance of all and underpinning coexistence and civility. Its distinctive feature is openness to the whole community. Thus, it actively establishes a consensus so that families, associations and volunteers are actively involved in school management and learning activities during the official school timetable (GovAndalusia-MoE, 2012).

In Catalonia, the plan of the government aimed at fostering school success by strengthening teachers professionalism, delivering personal support, innovating pedagogic methods, involving families in school life, providing new opportunities to early school leavers and other lines of action that operated within schools (GovCatalonia-MoE, 2012). According to the presentation of the minister to the Parliament, this approach was also a conclusion of an evidence-based review of European policies.

How can we achieve these goals? How did we find out the means to achieve them? To start with, we analysed the international literature and adopted the mainstream guidelines. Additionally, we became aware that we had to implement those guidelines simultaneously. They do not form a sequence but a set of simultaneous measures. It is crucial to know which synergies this simultaneous implementation generates. Finally, we took into consideration our expectations for Catalonia as a country, what we want to be in social and economic terms, that is, we adopt a set of simultaneous measures that are grounded on international research and contribute to meet our national expectations” (Rigau, 2012: 8).

In the former section a comparison of the official discourses of European and Spanish educational authorities found out that they retrieved a common 'frame' but understood prevention in disparate ways. In this section, it is plausible to conclude that they used different 'theories of change'. While the European institutions highlighted the importance of encompassing preventative policies, Spanish authorities mostly relied on the alleged effect of internal school processes. The former claimed their guidelines drew on the debates hold by an international group gathering experts with policy-makers. The latter claimed their approach was the straightforward result of the available 
scientific evidence. So, the main finding of this comparative discourse analysis of the two levels of governance notices that both framed the issue in similar terms but disagreed with regard to the best means to achieve the goal.

\section{Discussion and concluding remarks}

In a nutshell, a discourse analysis of the guidelines, laws and reports on early school leaving issued by the European institutions and a (small but varied) sample of educational authorities in Spain points at some similarities and differences. Apparently, all these political actors convey their messages within the same 'frame' since they widely agree that early school leaving is a big problem. However, an implicit but striking disagreement emerges with regard to the concept of prevention and the 'theories of change' that underlie their approaches. While the EU recommends an encompassing approach, in Spain most authorities adopt a much narrower perspective. Mostly, EU documents advise to prevent the problem by counter-acting segregation, supporting schools in disadvantaged areas and promoting an encouraging curriculum. In contrast, in Spain authorities think that the main solution lies in diversifying school tracks, experimenting with innovative pedagogies and strengthening the role of principals. These orders of priorities are clearly different.

While educational studies highlight the perverse effects of the current misunderstandings with regard to policies against early school leaving, European policy studies highlight how common these misunderstandings are in a variety of policy areas. For sure, it is disappointing that the member state which scores the highest proportion of early school leavers deflects the recommendation to prevent the problem (Timmerman \& Willems, 2015). However, if 'resistance' indicates that anomalous processes are at stake, the term must be significantly qualified. Whatever the disappointment for objectives with regard to early school leavers, the discrepancy between the EU and educational authorities in Spain is not a sign of tension. On the contrary, this finding unveils the complexity of policy learning. Both experts in EU policy-making (Radaelli et al, 2013) and EU education policy (Alexiadou and Lange, 2013) have convincingly noticed that the involved political actors continuously negotiate the meaning of the policy at stake. This observation also suggests questions on the effective policy learning that results from the transfer of discourses (as shaped by 'frames') and approaches or causal narratives (as indicated by 'theories of change'). 
By looking at the prevailing policies against early school leaving in Spain, this article finds out two pieces of evidence that contribute to spell out some clues of policy learning. On the one hand, the EU, the Government of Spain and a variety of regional governments share the same 'frame' as portrayed by the same catchwords. This does not seem to posit a particular problem but transmits a sense of agreement. Although their consensus is weak, all the political players eventually state they attempt to follow the same guidelines. On the other hand, albeit subtle, discrepancies with regard to the 'theory of change' are significant. Crucial to my argument is that these discrepancies are likely to affect implementation and outcomes significantly.

Lange and Alexiadou (2010)'s typology of modes of policy learning is extremely helpful to make sense of this finding. Between 2012 and 2012 in Spain educational authorities engaged in 'competitive’ policy learning of policies against early school leaving. These authorities were really concerned with meeting the official statistical benchmarks although this concern did not entail a full discussion of the underlying 'theory of change'. This is not an exceptional situation but a given state of a social field. It was a stable state for some years, and may be so for longer, but this stability has to be assessed empirically over time.

\section{References}

Adler-Nissen, R., and Kropp, K. 2015. A Sociology of Knowledge Approach to European llIntegration: Four Analytical Principles. Journal of European Integration 372, no. 3: 155173.

Alexiadou, N., Fink-Hafner, D., and Lange, B. 2010. Education Policy Convergence through the Open Method of Coordination: Theoretical Reflections and Implementation in 'old' and 'new’ National Contexts. European Educational Research Journal 9, no. 3: 345-358.

Alexiadou, N., and Lange, B. 2013. Deflecting European Union Influence on National Education Policy-Making: The Case of the United Kingdom. Journal of European Integration 35, no. 1: 37-52.

Auld, E., and Morris, P. 2014. Comparative Education, the 'New Paradigm' and Policy Borrowing: Constructing Knowledge for Educational Reform. Comparative Education 50, no. 2: 129155.

Benford, R.D., and Snow, D.A. 2000. Processes and Social Movements: An Overview and Assessment. Annual Review of Sociology 26: 611-639.

Brunello, G., and De Paola, M. 2013. The Costs of Early School Leaving. European Expert Network on Economics of Education (EENEE) Analytic Reportsno. 17: 1-46.

Carstensen, Martin B., Schmidt, V. A. 2016. Power Through, over and in Ideas: Conceptualizing Ideational Power in Discursive Institutionalism. Journal of European Public Policy 23, no. 3: 318-337.

Confederation of Family Associations in the European Union. 2010. COFACE Position on Early 
School Leavers and the Role of Parents. Brussels: European Commission.

Corbin, J. \& Strauss, A. (1990) Grounded Theory Research: Procedures, Canons, and Evaluative Criteria. Qualitative Sociology, 13(1): 3-21.

Croxford, L., Grek, S., and Shaik, F.J. 2009. Quality Assurance and Evaluation (QAE) in Scotland: Promoting Self evaluation within and beyond the Country. Journal of Education Policy 24, no. 2: 179-193.

Dale, R., and Robertson, S. 2009. Globalisation and Europeanisation in Education. London: Symposium Books.

Davis Cross, M.A. 2013. Rethinking Epistemic Communities Twenty Years Later. Review of International Studies 39: 137-160.

Diez, Th. 1999. Speaking 'Europe': The Politics of Integration Discourse. Journal of European Public Policy 6, no. 4: 598-613.

Dupuy, C. 2012. La Course Vers Le Milieu Des Régions. Compétition et Politiques Régionales D’éducation En France et En Allemagne. Canadian Journal of Political Science / Revue Canadienne de Science Politique 45, no. 4: 881-907.

European Commission. 2013c. CALL FOR PROPOSALS — EACEA/04/13 Under the Lifelong Learning Programme Implementation of the European Strategic Objectives in Education and Training ('ET 2020') (stakeholder Cooperation, Experimentation and Innovation) (2013/C 118/07). Official Journal of the European Unionno. C 118: 27-31. . 2012a. Conference Report: Reducing Early School Leaving: Efficient and Effective Policies in Europe. Lifelong Learning: Policies and Programme School Education; Comenius: $1-18$. . 2013a. Early Warning Systems in Europe: Practice, Methods and Lessons. Thematic Working Group on Early School Leaving. Brussels: European Commission. . 2013b. Overview and Examples of Costs of Early School Leaving in Europe. Thematic Working Group on Early School Leaving. Brussels: European Commission. . 2012c. Reducing Early School Leaving in France. Thematic Working Group on Early School Leaving. Brussels: European Commission. . 2012d. Reducing Early School Leaving in the Netherlands. Thematic Working Group on Early School Leaving. Brussels: European Commission. . 2013d. Reducing Early School Leaving: Key Messages and Policy Support. Final Report of the Thematic Working Group on Early School Leaving. Brussels: European Commission. . 2011. Reducing Early School Leaving Accompanying Document to the Proposal for a Council Recommendation on Policies to Reduce Early School Leaving. Commission Staff Working Papers SEC(2011) 96 final: 1-37.

. 2012. Education and Training Monitor. Luxembourg: Publications Office of the European Union.

European Commission, EACEA, and EURYDICE. 2013. Education and Training in Europe 2020: Responses from the EU Member States. Eurydice Report. Brussels: EURYDICE.

European Commission, EACEA, EURYDICE, and CEDEFOP. 2014. Tackling Early Leaving from Education and Training in Europe: Strategies, Policies and Measures. Luxembourg: Publications of the European Union.

European Council. 2011. Council Recommendation of 28 June 2011 on Policies to Reduce Early School Leaving. Official Journal of the European Union: C191/1-3.

European Network of Education Councils (EUNEC). 2014. Early School Leaving. Report of the EUNEC Conference (Vilnius, 8-10 Nov 2013). Brussels: EUNEC Secretariat, European Commission DG Education and Culture.

European Trade Union Conference on Education. 2011. ETUCE Statement on the Proposal for a 
Council Recommendation on Early School Leaving. Brussels: Published by the ETUCE. . 2013. Preventing Early School Leaving through the Use of ICT in Education. Funded by the EC Lifelong Learning Project. Brussels: Published by the ETUCE.

European Union. 2009. Council Conclusions of 12 May 2009 on a Strategic Framework for European Cooperation in Education and Training ('ET 2020'). Official Journal of the European Union C 119/2: 2-7.

EUROSTAT. 2014. Tables on EU Policy. Europe 2020 Indicators. Headline Indicators. Education. In Statistics. Brussels: EUROSTAT.

Fairclough, N. 2003. Critical Discourse Analysis: The Critical Study of Language. London: Longman.

Goffman, E. 1997. Frames and the Organization of Experience. In The Goffman Reader, 147-262. Charles Lemert and Ann Branaman. Malden (MA): Blackwell.

Government of Andalusia- Ministry of Education (GovAndalusia-MoE). 2007. Ley 17/2007, de 10 de Diciembre, de Educación de Andalucía [Andalusia Education Act]. Boletín Oficial de la Junta de Andalucía [Official Bulletin of the Government of Andalusia]. 252: 5-36. . 2011. ORDEN de 5 de Julio de 2011, Conjunta de Las Consejerías de Educación Y Empleo, Por La Que Se Establecen Las Bases Reguladoras de La Beca 6000, Dirigida a Facilitar La Permanencia En El Sistema Educativo Del Alumnado de Bachillerato Y de Ciclos Formativos de Grado Medio de Formación Profesional Inicial Y Se Efectúa Su Convocatoria Para El Curso 2011/2012 [Order of 5th July 2011, Sponsored by the Ministries of Education and Employment, Regulating Scholarship 2006, Which Underpins the Completion of Baccaleaurat and Vocational Training Courses. Call for the 2011-12 Year]. Boletín Oficial de la Junta de Andalucía [Official Bulletin of the Government of Andalusia]. 141. 9-11.

2012. Orden de 8 de Junio de 2012, Por La Que Se Regula El Procedimiento De Inscripción Y Continuidad De Centros Reconocidos Como «Comunidad de Aprendizaje» Y Se Crea La Red Andaluza «Comunidades de Aprendizaje» [Order of 8th June 2012, Which Regulates The Register of Schools as «Learning Communities»] Boletín Oficial de la Junta de Andalucía [Official Bulletin of the Government of Andalusia] 126: 46-59.

2016. Beca 6000. Información General. Government of Andalusia Web Page. [Retrieved on Nov $15^{\text {th }}$ 2016] http://www.juntadeandalucia.es/educacion

Government of Catalonia- Ministry of Education (GovCat-MoE). 2012. Ofensiva de País a Favor de L'èxit Escolar. Pla per a La Reducció Del Fracàs Escolar a Catalunya 2012-2018 [Endeavour for School Success. Plan for Reducing School Failure in Catalonia, 20122018]. Barcelona: Generalitat de Catalunya.

Government of Spain- Ministry of Education (GovSpain-MoE). 2006. Ley Orgánica 2/2006, de 3 de Mayo, de Educación [Organic Act 2/2006, May 3 $3^{\text {rd }}$, on Education]. Boletín Oficial Del Estado [Official Bulletin of the State]. 106: 17158-17207.

. 2013a. Ley Orgánica 8/2013, de 9 de Diciembre, Para La Mejora de La Calidad Educativa [Organic Act 8/2013, December $9^{\text {th }}$, on Improving the Quality of Education]. Boletín Oficial Del Estado [Official Bulletin of the State]. 295: 97858-97921.

. 2013b. Informe 2013: Objetivos Educativos Europeos Y Españoles. Educación Y Formación 2020 [2013 Report: European and Spanish Education and Training 2010 Goals]. Madrid: MECD- GovSpain.

Grek, S. 2010. International Organisations and the Shared Construction of Policy 'Problems': Problematisation and Change in Education Governance in Europe. European Educational Research Journal 9, no. 3: 396-406. . 2013. Expert Moves: International Comparative Testing and the Rise of Expertocracy. 
Journal of Education Policy 28, no. 5: 695-709.

Grek, S., Lawn, M., Lingard, B., Ozga, J., Rinne, R., Segerholm, C., and Simola, H. 2009a.

National Policy Brokering and the Construction of the European Education Space in

England, Sweden, Finland and Scotland. Comparative Education 45, no. 1: 5-21.

Grek, S., Lawn, M., Lingard, B., and Varjo, J. 2009b. North by Northwest: Quality Assurance and Evaluation Processes in European Education. Journal of Education Policy 24, no. 2: 121133.

Grek, S., and Ozga, J. 2009. Governing Education through Data: Scotland, England and the European Education Policy Space. British Journal of Educational Research 36, no. 6: 937952.

Huang, R. 2014. RQDA: R-Based Qualitative Data Analysis. R Package Version 0.2-6. URL http://rqda.r-forge.r-project.org/. http://rqda.r-forge.r-project.org/.

Jackson, E. T. (2013): Interrogating the theory of change: evaluating impact investing where it matters most, Journal of Sustainable Finance \& Investment, 3, no 2: 95-110.

Jessop, B. 2007. State Power: A Strategic- Relational Approach. London: Polity.

Keating, M. 2009. Rescaling Europe. Perspectives on European Politics and Society 10, no. 1: 3450.

Lange, B., and Alexiadou, N. 2007. New Forms of European Union Governance in the Education Sector? A Preliminary Analysis of the Open Method of Coordination. European Educational Research Journal 6, no. 4: 321-335. 2010. Policy Learning and Governance of Education Policy in the EU. Journal of Education Policy 25, no. 4: 443-463.

Lingard, B., Martino, W., and Rezai-Rashti, G. 2013. Testing Regimes, Accountabilities and Education Policy: Commensurate Global and National Developments. Journal of Education Policy 28, no. 5: 539-556.

Manzanares, A., and Ulla, S. 2012. La Evaluación Estatal Del Plan de Refuerzo, Orientación Y Apoyo (PROA). Análisis Tras Seis Años de Evaluación Continuada. Revista de Educación Número extraordinario: 89-116.

Network of Experts in Social Sciences of Education and Training (NESSE). 2009. Early School Leaving. Lessons from Research for Policy Makers. Paris: INRP (http://www.nesse.fr).

Nicaise, I. 2012. A Smart Social Inclusion Policy for the EU: The Role of Education and Training. European Journal of Education 47, no. 2: 327-342.

Normand, R. 2010. Expertise, Networks and Indicators: The Construction of the European Strategy in Education. European Educational Research Journal 9, no. 3: 407-422.

OECD. 2014b. TALIS 2013 Results. An International Perspective on Teaching and Learning. Paris: OECD.

2007. No More Failures: Ten Steps to Equity in Education. Paris: OECD Publishing. . 2011. PISA 2009 Results: Overcoming Social Background Equity in Learning Opportunities and Outcomes. Vol. 2. Paris: OECD. . 2012. Equity and Quality in Education: Supporting Disadvantaged Students and Schools. Paris: OECD Publishing. . OECD 2012 Results: What Makes a School Successful? Vol. 4. Paris: OECD.

Oomen, A., and Plang, P. 2014. Early School Leaving \& Lifelong Guidance. ELGPN Conceptual Notes 6: 1-40.

Ozga, J. S., Dahler-Larsen, P., and Segerholm, Ch. 2011a. Europe in Translation. In Fabricating Quality in Education. Data and Governance in Europe, 76-82. Jenny Ozga, Peter DahlerLarsen, Chrisitina Segerholm and Hannu Simola. London and New York: Routledge.

Ozga, J. S., Segerholm, Ch., and Simola, H. 2011b. The Governance Turn. In Fabricating Quality 
in Education. Data and Governance in Europe, 85-95. Jenny Ozga, Peter Dahler-Larsen, Chrisitina Segerholm and Hannu Simola. London and New York: Routledge.

Parreira do Amaral, M., Dale, R., Loncle, P. 2015. Shaping the Futures of Young Europeans. Education Governance in Eight European Countries. Oxford (UK): Symposium Books.

Pépin, L. 2011. Education in the Lisbon Strategy: Assessment and Prospects. European Journal of Education 46, no. 1: 25-35.

Radaelli, C., Dunlop, C., and Fritsch, O. 2013. Narrating Impacts Assessment in the European Union. European Political Science 12: 500-521.

Rambla, X. 2013. Planning, Re-Bordering and Setting Times: A Comparative Analysis of European and Latin American 'Education Spaces’. Globalisation, Societies, Education. 11(4): 520537.

Rigau, I. 2012. Sessió Informativa Amb La Consellera d'Ensenyament Sobre El Pla de Xoc Contra El Fracàs Escolar [The Minister Presents the Plan for School Success to the Parliament] (tram. 355-00090/09). Diari de Sessions Del Parlament de Catalunya IX Legislatura-Sèrie C-Num 355, no. Comissió d’Ensenyament i Universitats, sessió num 23: 3-10.

Rogers, P. J. 2008. Using Programme Theory to Evaluate Complicated and Complex Aspects of Interventions. Evaluation 14(1): 29 - 48.

Ruiter, A. de. 2010. Variations on a Theme. Governing the Knowledge Based Society in the EU through Methods of Open Coordination in Education and R\&D. Journal of European Integration 32, no. 2: 157-173.

Schmidt, V. A. 2008. Discursive Institutionalism: The Explanatory Power of Ideas and Discourse. Annual Review of Political Science 11: 303-26.

Simola, H., Ozga, J. S., Segerholm, Ch., Varjo, J., and Andersen, V. N. 2011. Governing by Numbers. The Rise of Data in Education. In Fabricating Quality in Education. Data and Governance in Europe, 96-106. Jenny Ozga, Peter Dahler-Larsen, Chrisitina Segerholm and Hannu Simola. London and New York: Routledge.

Stame, N. 2004. Theory-based Evaluation and Types of Complexity. Evaluation 10, no 1: 58-76.

Stéger, C. 2014. Review and Analysis of the EU Teacher-Related Policies and Activities. European Journal of Education 49, no. 3: 332-347.

Stein, D. and Valters, C. 2012. Understanding 'theory of change' in international development. Justice and Security Research Programme Papers (London School of Economics), 1: 1-25

Timmerman, C., and Willems, R. 2015. Policies on Early School Leaving in Nine European Countries: A Comparative Analysis. Antwerpen: Reducing ESL Network (FP7 Project $n^{\circ}$ 320223).

Vogel, R. 2012. Framing and Counter-Framing New Public Management: The Case of Germany. Public Administration 90, no. 2: 370-392.

Wert, J. I. 2013. Proyecto de Ley Orgánica Para La Mejora de La Calidad Educativa . El Señor Ministro de Educación, Cultura Y Deporte Presenta a La Cámara El Proyecto de Ley de Referencia [Project of an Organic Act for School Quality Improvement. The Minister of Education, Culture and Sports Presents the Project to the Parliament]. Diario de Sesiones Del Congreso de Los Diputados 129, no. 16 julio 2013: 4-50.ov 
Table 1 Corpus of discourse

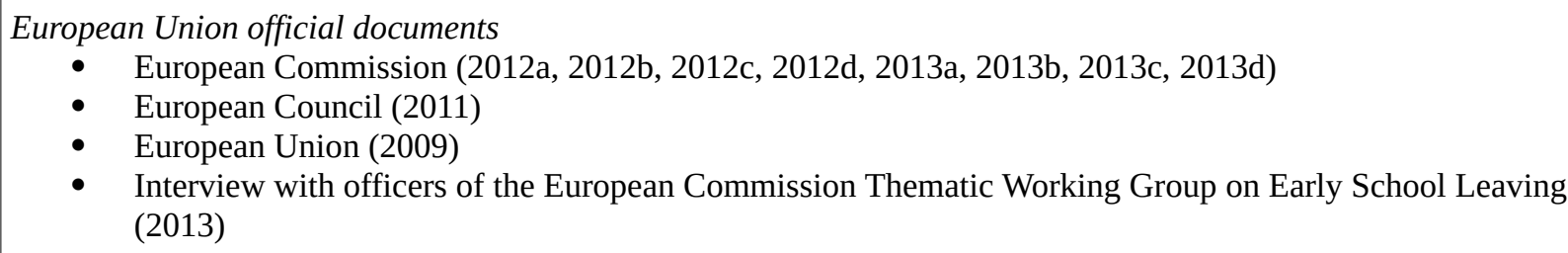

- Interview with officers of the European Commission Thematic Working Group on Early School Leaving (2013)

OECD, networks of experts and civil society representatives

- $\quad$ Organisation for Economic Cooperation and Development $(2007,2012)$

- $\quad$ Network of Experts in Social Sciences of Education and Training (NESSE, 2009)

- European Experts Network in Economics of education (Brunallo \& Di Paola, 2013)

- $\quad$ European Union Network of Educational Councils (EUNEC, 2014)

- $\quad$ European Lifelong Guidance Policy Network (Oomen \& Plang, 2014)

- $\quad$ Confederation of Family Associations in the European Union (COFACE, 2010)

- $\quad$ European teachers union (ETUCE, 2011, 2013)

Government of Spain

- $\quad$ Organic Law on the Education (GovSpain-MoE, 2006) and Organic Law for Improving the Quality of Education (GovSpain-MoE, 2013)

- $\quad$ Report on early school leaving policies (GovSpain-MoE, 2013)

- $\quad$ Report of the Education Minister to the Parliament (Wert, 2013)

- Group interview with the technical staff involved in writing the Organic Law for Improving the Quality of Education (2013)

Government of Andalusia

- $\quad$ Andalusia Education Act (GovAndalusia-MoE, 2007)

- 6000 Scholarship decree (GovAndalusia-MoE, 2011) and website description (GovAndalusia-MoE, 2016)

- $\quad$ Decree on Learning Communities (GovAndalusia-MoE, 2012)

Government of Catalonia

- $\quad$ 'Success' Plan of Action in Education (GenCat-MoE, 2012)

- $\quad$ Report of the Education Minister to the Parliament (Rigau, 2012)

- Interviews with managers and technical staff of the Ministry of Education (2012-3) 